\title{
Pathways of ethanol production from sucrose by a mutant thermophilic Bacillus in continuous culture
}

\author{
Ricardo San Martin, $\dagger$ Des Bushell, David J. Leak* and Brian S. Hartley \\ Centre for Biotechnology, Imperial College of Science, Technology and Medicine, London SW7 2AZ, UK \\ (Received 3 August 1992; revised 8 December 1992; accepted 5 January 1993)
}

\begin{abstract}
A mutant (strain LLD-15) of Bacillus stearothermophilus strain LLD-R, that lacks L-lactate dehydrogenase activity was studied in anaerobic single-stage continuous culture using a defined minimal medium for its capacity to produce ethanol from sucrose at $70{ }^{\circ} \mathrm{C}$. Cultures were stable at neutral $\mathrm{pH}$, dilution rates below $0.25 \mathrm{~h}^{-1}$ and sucrose concentrations below $15 \mathrm{~g} \mathrm{l}^{-1}$, producing mainly ethanol, $\mathrm{CO}_{2}$, formate and acetate plus a little succinate. The data obtained were used to estimate the maintenance energy coefficient at $70{ }^{\circ} \mathrm{C}$ and showed that the relative fluxes through the pyruvate-formate lyase (PFL) pathway and an anaerobic pyruvate dehydrogenase (PDH) pathway were about equal, though the later predominates at low dilution rates. At higher dilution rates or at acid pH, L-lactate became the major anaerobic product due to takeover by wild-type revertants. Reversion occurred

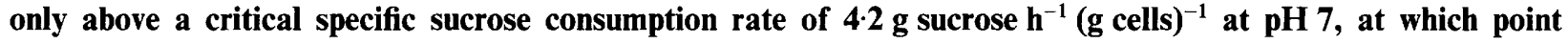
pyruvate production was also seen. This can be attributed to saturation of the PFL pathway and PDH pathways by increasing glycolytic flux and consequent accumulation of intracellular pyruvate. The growth rate then declines, but a small population of revertant LLD-R cells would always be present in the bioreactor since the mutation in the L-lactate dehydrogenase gene has a significant reversion rate. These revertants have no selective advantage below the critical sugar uptake rate, but at higher rates they divert excess pyruvate to L-lactate, so their growth is unimpaired and they take over in the culture. At lower $\mathrm{pH}$, growth restriction and reversion occur at low sucrose consumption rates due to difficulty in excreting acetic and formic acids against a pH gradient.
\end{abstract}

\section{Introduction}

The use of thermophilic bacteria for production of fuelgrade ethanol offers important advantages over traditional yeast processes. In a process operated above $65^{\circ} \mathrm{C}$, ethanol is easily removed in the vapour by sparging or mild vacuum (Maiorella et al., 1984), decreasing end-product inhibition and lowering separation costs. Moreover, many thermophilic bacteria can ferment a wide variety of sugars including pentoses, and so could be used to produce ethanol from low-cost lignocellulosic hydrolysates. However, unlike yeasts and Zymomonas species, most thermophiles produce little ethanol; lactate, formate and acetate are normally the major anaerobic products.

*Author for correspondence. Tel. (071) 5895111 ; fax (071) 2258942.

$\dagger$ Present address: Universidad Católica, Departmento de Ingeniería Química, Vicuña Mackenna 4860, Casilla 6177, Santiago, Chile.

Abbreviations: PDH, pyruvate dehydrogenase; PFL, pyruvateformate lyase.
To construct an ethanol-producing thermophile, Payton \& Hartley (1985) screened for a thermophilic Bacillus that grew rapidly anaerobically at $70^{\circ} \mathrm{C}$. This strain was originally believed to be the well-known $B$. stearothermophilus strain NCA 1503, but further characterization (Hartley, 1988; Amartey et al., 1991) showed that it was a novel organism, deposited as Bacillus stearothermophilus strain LLD-R (NCIB 12403). By screening for fluoropyruvate resistance, a spontaneous mutant of this thermophile was selected that lacked L-lactate dehydrogenase (strain LLD-15; NCIB 12428). The rationale was that the pyruvate arising from glycolysis would then be diverted via pyruvate-formate lyase (PFL) to produce acetate, ethanol and formate in a $1: 1: 2$ ratio (per mol of hexose). The ethanol yield would still be uncompetitive with yeasts, but further physiological or genetic manipulations to decrease PFL flux might cause the accumulating intracellular pyruvate to be diverted via pyruvate dehydrogenase (PDH; then believed to be active only aerobically) to give 2 ethanol $+2 \mathrm{CO}_{2}$ per mol of hexose, like yeast.

Hartley \& Shama (1987) showed the above speculation 
to be correct. The PFL pathway predominates in anaerobic batch cultures on sucrose at $70^{\circ} \mathrm{C}$ at high $\mathrm{pH}$, but at acid $\mathrm{pH}$ high yields of ethanol and $\mathrm{CO}_{2}$ were seen, consistent with flux through PDH (which appeared to have unchanged levels in both aerobic and anaerobic cells). The switch to the PDH pathway appeared to be due to increasing levels of acetate and formate in the broth and coincided with a slowing in growth rate. When growth eventually stopped, sucrose continued to be metabolized entirely to ethanol $+\mathrm{CO}_{2}$ by the PDH pathway, suggesting that this was the sole route for maintenance metabolism under these conditions.

Continuous culture is an obvious tool to unravel these phenomena, but this had to await development of a defined minimal medium for the anaerobic cultivation of

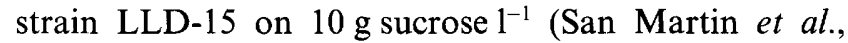
1992). In the present work, this has allowed determination of detailed material and energy balances that can be related to growth and maintenance metabolism. However, the continuous cultures were stable only at dilution rates below $0.3 \mathrm{~h}^{-1}$; above this value, lactate was detected in the broth, due to take-over by the revertant strain LLD-R. This suggests that the lactate pathway confers little growth advantage at low dilution rates, but is an important pathway of 'overflow metabolism' when sugar utilization rates increase above a critical threshold.

\section{Methods}

Strains and media. The mutant strain Bacillus stearothermophilus strain LLD-15 (NCIB 12428) and the revertant strain LLD-R (NCIB 12403) have been described previously (San Martin et al., 1992). The defined minimal medium BST-AMM developed by San Martin et al. (1992) for $10 \mathrm{~g}$ input sucrose $\mathrm{l}^{-1}$ was the basis for developing the media for 15 and $20 \mathrm{~g}$ input sucrose $1^{-1}$ (Table 1). Batch experiments were performed to detect possible growth inhibition due to increased concentrations of salts, amino acids and vitamins. In all cases, complete sucrose utilization occurred and growth inhibition due to media composition was not detected.

For batch and continuous cultures, the salt solution was sterilized separately and after cooling to room temperature the amino acids and vitamins were added using $0.2 \mu \mathrm{m}$ sterile filters (Gelman). In all cases, sucrose was autoclaved separately.

All amino acids and vitamins were 'cell culture tested' grade (Sigma). Each amino acid was dissolved separately and filter-sterilized before being added to the basic salt medium. In the case of methionine and isoleucine, it was necessary to heat to approximately $50{ }^{\circ} \mathrm{C}$ to achieve complete dissolution. All of the vitamins were dissolved together in approximately $100 \mathrm{ml}$ of distilled water and filter-sterilized. All salts were analytical grade (BDH) and distilled water was used throughout.

Bioreactor operation and analyses. All experiments were carried out at $70^{\circ} \mathrm{C}$ in a 2 litre bioreactor with 1.5 litre working volume (Life Science Laboratories), prepared and operated as described by San Martin et al. (1992). Periodic analyses of biomass, sucrose, ethanol, lactic, formic, acetic and succinic acids were performed as previously described (San Martin et al., 1992).

In experiments at 10 and $15 \mathrm{~g}$ input sucrose $\mathrm{l}^{-1}$, the bioreactor was sparged with $50 \mathrm{ml}$ oxygen-free nitrogen $\mathrm{min}^{-1}$ to maintain anaerobic conditions. To monitor $\mathrm{CO}_{2}$ production, the output gases were passed through a stainless steel condenser located on top of the bioreactor, kept between -2 to $-5^{\circ} \mathrm{C}$ using a Grant FC 25 chiller and FH 15A heater/circulator in combination (Grant Instruments) for the refrigerant $(40 \%, \mathrm{v} / \mathrm{v}$, ethylene glycol). The gases were then filtered through $0.3 \mu \mathrm{m}$ filters (Gamma 12, Whatman), and dried by passing through containers of anhydrous calcium sulphate (Hammond Drierite). Gas analysis was performed on-line using a quadrupole mass spectrometer (model $200 \mathrm{~F}$, VG Gas Analysis) equipped with a 16-way multiport stream selector. The spectrometer was calibrated every $24 \mathrm{~h}$ using the following standard gas mixtures (BOC): calibration gas $1, \mathrm{~N}_{2}(85 \cdot 1 \%)$, $\mathrm{O}_{2}(9.3 \%), \mathrm{CO}_{2}(1.98 \%), \mathrm{CH}_{4}(2.59 \%)$ and $\mathrm{Ar}(1.03 \%)$; calibration gas $2, \mathrm{He}$; calibration gas 3 , compressed air.

In experiments at $20 \mathrm{~g}$ input sucrose $1^{-1}$, an increased nitrogen flow $\left(200 \mathrm{ml} \mathrm{min}^{-1}\right)$ was used to improve ethanol removal. The exiting gases were passed through a vertical condenser located outside the bioreactor, maintained at -2 to $-5{ }^{\circ} \mathrm{C}$ as above, and the distillate was collected in a separate reservoir.

To prevent take-over by revertants (see Results ad Discussion), continuous culture experiments at $20 \mathrm{~g}$ sucrose $\mathrm{1}^{-1}$ were initiated by starting the culture at $10 \mathrm{~g}$ input sucrose $\mathrm{I}^{-1} / \mathrm{BST}-\mathrm{AMM}$ and steadystate was attained at $D=0.2 \mathrm{~h}^{-1}$ at a substrate input rate of $2 \mathrm{~g}$ sucrose $1^{-1} \mathrm{~h}^{-1}$. Then the reservoir was changed to $20 \mathrm{~g}$ input sucrose $\mathrm{l}^{-1} /$ BST-AMM, and the dilution rate was reduced to $0 \cdot 1 \mathrm{~h}^{-1}$ to attain the same sucrose input rate. Simultaneously, the nitrogen flow was increased from $50 \mathrm{ml} \mathrm{min}{ }^{-1}$ to $200 \mathrm{ml} \mathrm{min}^{-1}$ and the ethanol removal system was connected.

Carbon and redox balance equations. (A list detailing the nomenclature used is given in an appendix following Results and

Table 1. Defined BST-AMM media used for continuous cultures

\begin{tabular}{|c|c|c|c|c|}
\hline Component & & Concen & ntration & \\
\hline \multicolumn{5}{|l|}{ Main components $\left(g l^{-1}\right)$} \\
\hline Sucrose & $5 \cdot 0$ & $10 \cdot 0$ & $15 \cdot 0$ & $20 \cdot 0$ \\
\hline Citric acid & 0.32 & $0 \cdot 32$ & 0.32 & 0.32 \\
\hline $\mathrm{MgSO}_{4} \cdot 7 \mathrm{H}_{2} \mathrm{O}$ & $0 \cdot 27$ & $0 \cdot 27$ & $0 \cdot 30$ & $0 \cdot 50$ \\
\hline $\mathrm{Na}_{2} \mathrm{HPO}_{4} \cdot 2 \mathrm{H}_{2} \mathrm{O}$ & $0 \cdot 13$ & $0 \cdot 13$ & $0 \cdot 26$ & 0.50 \\
\hline $\mathrm{K}_{2} \mathrm{SO}_{4}$ & $0 \cdot 50$ & $\cdot 0 \cdot 50$ & 0.50 & 0.50 \\
\hline $\mathrm{NH}_{4} \mathrm{Cl}$ & $2 \cdot 0$ & $2 \cdot 0$ & $2 \cdot 0$ & $3 \cdot 0$ \\
\hline \multicolumn{5}{|l|}{ Other minerals $\left(\mathrm{mg} \mathrm{l}^{-1}\right)$} \\
\hline $\mathrm{CaCl}_{2} \cdot 2 \mathrm{H}_{2} \mathrm{O}$ & $2 \cdot 5$ & $2 \cdot 5$ & $5 \cdot 0$ & $5 \cdot 0$ \\
\hline $\mathrm{MnCl}_{2} \cdot 4 \mathrm{H}_{2} \mathrm{O}$ & $3 \cdot 0$ & $3 \cdot 0$ & $3 \cdot 6$ & $4 \cdot 8$ \\
\hline Trace element solution $\left(\mathrm{mll}^{-1}\right)^{*}$ & $0 \cdot 25$ & 0.25 & $0 \cdot 35$ & 0.5 \\
\hline \multicolumn{5}{|l|}{ Amino acids $\left(m g l^{-1}\right)$} \\
\hline Isoleucine & 100 & 150 & 150 & 300 \\
\hline Serine & 150 & 150 & 150 & 300 \\
\hline Glutamic acid & 400 & 400 & 400 & 600 \\
\hline Methionine & 100 & 150 & 150 & 300 \\
\hline \multicolumn{5}{|l|}{ Vitamins $\left(\mu g l^{-1}\right)$} \\
\hline Thiamin & 1000 & 1000 & 1000 & 2000 \\
\hline Riboflavin & 450 & 450 & 450 & 900 \\
\hline Nicotinic acid & 1500 & 1500 & 1500 & 3000 \\
\hline Pyridoxal & 450 & 450 & 450 & 900 \\
\hline Biotin & 1000 & 1000 & 1000 & 2000 \\
\hline $\mathrm{C} / \mathrm{N}$ molar ratio & $4 \cdot 7$ & $9 \cdot 4$ & $14 \cdot 1$ & $12 \cdot 5$ \\
\hline
\end{tabular}

*Trace element solution (mg l-1): $\mathrm{ZnSO}_{4} \cdot \mathrm{H}_{2} \mathrm{O}(320) ; \mathrm{H}_{3} \mathrm{BO}_{3}(80)$; $\mathrm{CoCl}_{2} \cdot 6 \mathrm{H}_{2} \mathrm{O} \quad(400) ; \mathrm{CuSO}_{4} \cdot 5 \mathrm{H}_{2} \mathrm{O} \quad(1600) ; \quad \mathrm{NiCl}_{2} \cdot 6 \mathrm{H}_{2} \mathrm{O} \quad(80)$; $\mathrm{FeCl}_{3} \cdot 6 \mathrm{H}_{2} \mathrm{O}(4300)$; EDTA (2000). 
Discussion.) The carbon balance (C-bal) was calculated assuming an elemental composition for biomass of $\mathrm{C}_{1.0} \mathrm{H}_{1.8} \mathrm{O}_{0.5} \mathrm{~N}_{0.2}$ with a formula weight of $24 \cdot 6$ (Roels, 1980).

$$
\text { C-bal }=\left[\left(\Sigma\left(Y_{\mathrm{p} / \mathrm{S}} n_{\mathrm{C} / \mathrm{pi}}\right)+n_{\mathrm{C} / \mathrm{x}} Y_{\mathrm{x} / \mathrm{S}}\right) / n_{\mathrm{C} / \mathrm{S}}\right] 100 \%
$$

The redox balance was calculated from the yields of products and biomass according to Roels (1980), where the generalized degree of reduction $\left(\gamma_{i}\right)$ for a compound of composition $\mathrm{C}_{a} \mathrm{H}_{b} \mathrm{O}_{c} \mathrm{~N}_{d}$ is calculated assuming $\gamma_{\mathrm{C}}=4, \gamma_{\mathrm{H}}=1, \gamma_{\mathrm{O}}=-2$ and $\gamma_{\mathrm{N}}=-3$ in the equation

$$
\gamma_{\mathrm{i}}=(4 a+b-2 c-3 d) / a
$$

The generalized reduction balance $(\gamma$-bal) can then be calculated as

$$
\gamma \text {-bal }=\left[\left(\Sigma\left(n_{\mathrm{C} / \mathrm{pi}} Y_{\mathrm{pi} / \mathrm{s}} \gamma_{\mathrm{pi}}\right)+n_{\mathrm{C} / \mathrm{x}} Y_{\mathrm{x} / \mathrm{s}} \gamma_{\mathrm{x}}\right) / n_{\mathrm{C} / \mathrm{s}} \gamma_{\mathrm{S}}\right] 100 \%
$$

Correction for vapour ethanol removal and dissolved $\mathrm{CO}_{2}$. Experimentally determined ethanol concentrations refer only to ethanol in the broth, including that returned in the condensate. Vapour ethanol losses due to incomplete condensation were estimated experimentally by passing a synthetic mixture through the system that mimicked the fermentation products at $10 \mathrm{~g}$ input sucrose $\mathrm{l}^{-1}$, i.e. $3 \mathrm{~g}$ ethanol $\mathrm{l}^{-1}$, $3 \mathrm{~g}$ formate $\mathrm{l}^{-1}, 1.7 \mathrm{~g}$ acetate $\mathrm{1}^{-1}$ and $0.7 \mathrm{~g}$ succinate $\mathrm{l}^{-1}$. This mixture was passed through the system at dilution rates of $0 \cdot 11$ and $0 \cdot 18 \mathrm{~h}^{-1}$ under conditions similar to those in the fermentation experiments, i.e. $70^{\circ} \mathrm{C}, \mathrm{pH} 7$, sparging with $50 \mathrm{ml}$ nitrogen $\mathrm{min}^{-1}$ and identical agitation rate and condenser operation. The ethanol losses were estimated from the difference between the ethanol in the input stream and the exit stream.

Low nitrogen sparging rates $\left(50 \mathrm{ml} \mathrm{min}^{-1}\right)$ were used to prevent excessive ethanol vapour losses, but this prevented accurate $\mathrm{CO}_{2}$ readings because the mass spectrometer ideally requires a minimum nitrogen flow rate of $70-100 \mathrm{ml} \mathrm{min}^{-1}$. Additionally, $\mathrm{CO}_{2}$ and bicarbonate dissolved in the broth $\left[\mathrm{CO}_{2}(\mathrm{l})\right]$ removed from the bioreactor via the liquid outflow, were not determined. Hence, the $\mathrm{CO}_{2}$ measurements were likely to be underestimates of the true productivity. Dissolved $\mathrm{CO}_{2}\left[\mathrm{CO}_{2}(\mathrm{l})\right]$ was estimated experimentally by sparging the bioreactor with $5 \% \mathrm{CO}_{2} / 95 \% \mathrm{~N}_{2}(\mathrm{v} / \mathrm{v})$ at $150 \mathrm{ml} \mathrm{min}^{-1}$ while operating continuously under the standard conditions at $D=0.4 \mathrm{~h}^{-1}$ with either medium BST-AMM or the synthetic product mixture described above. The $\mathrm{pH}$ was maintained at 7 throughout by automatic $\mathrm{pH}$ control. The amount of dissolved $\mathrm{CO}_{2}$ was estimated by the difference between input $\mathrm{CO}_{2}$ and exit $\mathrm{CO}_{2}$, as determined by the mass spectrometer. It should be recognized that this is a combined value which incorporates the bicarbonate that would be present at this $\mathrm{pH}$. As all of the experimental calculations referred to $\mathrm{pH} 7$, it was not necessary to calculate bicarbonate separately. However, at other $\mathrm{pH}$ values appropriate corrections should be made.

Theoretical correction for ethanol and $\mathrm{CO}_{2}$ losses. A better correction for these can be made by considering the probable pathways of product formation. The major products were ethanol and $\mathrm{CO}_{2}$ produced by the PDH pathway, and formate, acetate and ethanol produced by the PFL pathway, together with a little succinate that probably arises from phosphoenolpyruvate by $\mathrm{CO}_{2}$ fixation. Since redox balance must be reached in steady-state continuous culture, one can set $\gamma$-bal in equation (2) to $100 \%$ (total product recovery). Since the degree of reduction of $\mathrm{CO}_{2}$ is equal to zero, this equation then provides the theoretical ethanol yield

$$
\left(Y_{\mathrm{EtOH} / \mathrm{S}}\right)_{\text {theor }}=\left[n_{\mathrm{C} / \mathrm{S}} \gamma_{\mathrm{C} / \mathrm{S}}-K\right] /\left[\gamma_{\mathrm{EtOH}} n_{\mathrm{C} / \mathrm{EtOH}}\right]
$$

where $K=\Sigma\left(n_{\mathrm{C} / \mathrm{pi}} Y_{\mathrm{pi} / \mathrm{S}} \gamma_{\mathrm{pi}}\right)$ for all products but ethanol.

The rate of formate production is a good estimate of flux through the PFL pathway. Since one ethanol is produced for every two formates, the ethanol yield via the PFL pathway is

$$
\left(Y_{\mathrm{EtOH} / \mathrm{S}}\right)_{\mathrm{PFL} \text { pathway }}=\left(Y_{\text {formate } / \mathrm{S}}\right) / 2
$$

Since the rest of the ethanol is produced via the PDH pathway, its yield is

$$
\left(Y_{\mathrm{EtOH} / \mathrm{S}}\right)_{\mathrm{PDH} \text { pathway }}=\left(Y_{\mathrm{EtOH} / \mathrm{S}}\right)_{\text {theor }}-\left(Y_{\mathrm{EtOH} / \mathrm{S}}\right)_{\mathrm{PFL} \text { pathway }}
$$

The theoretical $\mathrm{CO}_{2}$ molar yield is the yield of ethanol produced via the PDH pathway less the $\mathrm{CO}_{2}$ utilized in succinate production, i.e.

$$
\left(Y_{\mathrm{CO}_{2} / \mathrm{s}}\right)_{\text {theor }}=\left(Y_{\mathrm{EtOH} / \mathrm{S}}\right)_{\mathrm{PDH} \text { pathway }}-\left(Y_{\text {succinate } / \mathrm{S}}\right)
$$

Finally, the consistency of the theoretical values was evaluated by checking that the carbon balance did not exceed $100 \%$.

Reproducibility of results. All chemical analyses were done in duplicate and are presented as the mean values. Much of the continuous culture work was repeated at least once to confirm the trends obtained. However, the results presented here are those from representative runs.

\section{Results and Discussion}

\section{Continuous cultures on $10 \mathrm{~g}$ sucrose $\mathrm{l}^{-1}$}

Table 2 shows the kinetic parameters and molar yields for strain LLD-15 grown on $10 \mathrm{~g}$ input sucrose $1^{-1}$. The culture remained stable at dilution rates below $0 \cdot 3 \mathrm{~h}^{-1}$. Above this value, lactate was detected in the broth, due to take over by the revertant strain LLD-R as discussed by San Martin et al. (1992). Within the stable region (i.e. $0 \cdot 1-0 \cdot 25 \mathrm{~h}^{-1}$ ), the molar ratio of formate to acetate remained relatively constant at approximately $2 \cdot 3: 1$, in fair agreement with the balance predicted by the PFL pathway. Observed yields of ethanol higher than those predicted by the PFL pathway $(0.7-0.8 \mathrm{~mol}$ per mol of fermented sucrose), together with significant $\mathrm{CO}_{2}$ production, suggested anaerobic operation of the $\mathrm{PDH}$ pathway.

Table 2 shows that experimental values for carbon and reduction balances were lower than expected. Formate, acetate, succinate and lactate levels are probably reliable, since acetate values were in good agreement by different assays with or without derivatization, and extensive analyses failed to reveal any other products. Hence significant losses in vapour ethanol and dissolved $\mathrm{CO}_{2}$ are indicated. The model experiments showed that about $15 \%$ of the ethanol was lost in the exit vapours when the nitrogen sparging rate was only $50 \mathrm{ml} \mathrm{min}{ }^{-1}$. In real experiments, the losses were probably even higher, depending on dilution rate, nitrogen sparging and condenser operation.

Significant amounts of $\mathrm{CO}_{2}$ are likely to be present in the culture broth as dissolved $\mathrm{CO}_{2}$ in equilibrium with bicarbonate. Very little $\mathrm{CO}_{2}$ was evolved when the influent BST-AMM medium was acidified, but $\mathrm{CO}_{2}$ equivalent to $4.4 \mathrm{mmol}^{-1}$ was released on acidification of the effluent broth. This represents approximately $15 \%$ of the total $\mathrm{CO}_{2}$ produced under those conditions. These results agree with observations for mesophilic anaerobic systems, where significant amounts of $\mathrm{CO}_{2}$ remain dissolved in the broth even after gas sparging (van 
Table 2. Kinetic data for the continuous culture of B. stearothermophilus $L L D-15$ under anaerobic conditions at $10 \mathrm{~g}$ input sucrose $l^{-1}$ in defined BST-AMM media, $\mathrm{pH} 7 \cdot 0,70^{\circ} \mathrm{C}$

\begin{tabular}{|c|c|c|c|c|c|c|c|c|c|c|c|c|}
\hline \multirow{2}{*}{$\begin{array}{c}D \\
\left(\mathrm{~h}^{-1}\right)\end{array}$} & \multicolumn{4}{|c|}{ Sucrose $\left[\mathrm{g} \mathrm{l}^{-1} ;(\%\right.$ used $\left.)\right]$} & \multirow{2}{*}{\multicolumn{2}{|c|}{$\begin{array}{l}\text { Cells } \\
\left(\mathrm{g} \mathrm{l}^{-1}\right)\end{array}$}} & \multirow{2}{*}{\multicolumn{2}{|c|}{$Y_{\mathrm{x} / \mathrm{s}}{ }^{*}$}} & \multirow[b]{2}{*}{$\mathrm{s}^{\dagger}$} & \multirow[b]{2}{*}{$q_{\mathrm{EtOH}} \ddagger$} & & \\
\hline & \multicolumn{2}{|c|}{ Uptake } & \multicolumn{2}{|c|}{ Catabolized } & & & & & & & & \\
\hline 0.10 & \multicolumn{2}{|c|}{$10.3(98 \%)$} & \multicolumn{2}{|c|}{$9.9(96 \%)$} & \multicolumn{2}{|c|}{0.38} & \multicolumn{2}{|c|}{0.037} & 60 & \multicolumn{2}{|c|}{$0.79(1.05)$} & \\
\hline $0 \cdot 15$ & \multicolumn{2}{|c|}{$10.7(98 \%)$} & \multicolumn{2}{|c|}{$10 \cdot 2(95 \%)$} & \multicolumn{2}{|c|}{0.51} & \multicolumn{2}{|c|}{0.048} & $3 \cdot 00$ & \multicolumn{2}{|c|}{$0.85(1.11)$} & \\
\hline $0 \cdot 20$ & \multirow{2}{*}{\multicolumn{2}{|c|}{$106(98 \%)$}} & \multicolumn{2}{|c|}{$10.0(94 \%)$} & \multicolumn{2}{|c|}{0.61} & \multicolumn{2}{|c|}{0.057} & $3 \cdot 28$ & \multicolumn{2}{|c|}{$0.83(1.18)$} & \\
\hline $0 \cdot 25$ & & & \multirow{2}{*}{\multicolumn{2}{|c|}{$\begin{array}{l}9.6(97 \%) \\
9.5(93 \%)\end{array}$}} & \multirow{2}{*}{\multicolumn{2}{|c|}{$\begin{array}{l}0.60 \\
0.70\end{array}$}} & \multirow{2}{*}{\multicolumn{2}{|c|}{$\begin{array}{l}0.059 \\
0.069\end{array}$}} & $4 \cdot 00$ & \multicolumn{2}{|c|}{$1.06(1.48)$} & \\
\hline $0 \cdot 30$ & \multicolumn{2}{|c|}{$10 \cdot 2(97 \%)$} & & & & & & & & $1.06(-)$ & & \\
\hline & & & & Prod & ts $(\mathrm{n}$ & & & & & & & \\
\hline$\left(h^{-1}\right)$ & $\mathrm{EtOH}$ & & $\mathrm{O}_{2}$ & Formate & & ate & & inate & & ctate & -bal (corr.) & $\gamma$-bal (corr.) \\
\hline $0 \cdot 10$ & $65(87)$ & & (54) & 46 & & & & $\cdot 5$ & & 83 & $33 \%(99 \%)$ & $85 \%(100 \%)$ \\
\hline $0 \cdot 15$ & $63(82)$ & & (47) & 50 & & & & & & 84 & $4 \%(98 \%)$ & $84 \%(100 \%)$ \\
\hline $0 \cdot 20$ & $57(78)$ & & (47) & 52 & & & & 4 & & 82 & $32 \%(98 \%)$ & $82 \%(100 \%)$ \\
\hline $0 \cdot 25$ & $57(77)$ & & (42) & 52 & & & & 0 & & 82 & $32 \%(98 \%)$ & $83 \%(100 \%)$ \\
\hline $0 \cdot 30$ & $54(-)$ & 24 & & 44 & & & & 2 & & 3 & - & - \\
\hline & & & Molar & yields $[\mathrm{n}$ & prc & uct ( & $\mathrm{mols}$ & crose & take & )$\left.^{-1}\right] \|$ & & \\
\hline$\left(\mathrm{h}^{-1}\right)$ & $\mathrm{EtOH}$ & & $\mathrm{CO}_{2}$ & For & ate & Ace & tate & Succ & late & Lactate & Cells & \\
\hline $0 \cdot 10$ & $2 \cdot 2(2 \cdot 9)$ & & $1 \cdot 1(1 \cdot 8)$ & & & 0 & & & & $0 \cdot 01$ & 0.5 & \\
\hline $0 \cdot 15$ & $2 \cdot 0(2 \cdot 6)$ & & $1 \cdot 1(1 \cdot 5)$ & & & 0 & & & & 0.01 & $0 \cdot 7$ & \\
\hline $0 \cdot 20$ & $1.8(2 \cdot 4)$ & & $0.9(1.5)$ & & & 0 & & & & 0.01 & 0.8 & \\
\hline $0 \cdot 25$ & $1.9(2.6)$ & & $0.8(1.4)$ & & & 0 & & & & 0.01 & 0.8 & \\
\hline $0 \cdot 30$ & $1.8(-)$ & & $0.8(-)$ & & & 0 & & & & 0.27 & 0.9 & \\
\hline
\end{tabular}

Catabolic pathway fluxes [g product $(\mathrm{g} \text { cells })^{-1} \mathrm{~h}^{-1} ;(\%$ used $\left.)\right] \|$

\begin{tabular}{|c|c|c|c|c|c|c|c|c|}
\hline \multirow{2}{*}{$\underset{\left(\mathrm{h}^{-1}\right)}{D}$} & \multicolumn{4}{|c|}{ PFL pathway } & \multicolumn{3}{|c|}{ PDH pathway } & \multirow{2}{*}{$\frac{\text { Succinate pathway }}{q_{\text {Succinate }}}$} \\
\hline & $q_{\mathrm{EtOH}}$ & $q_{\text {Formate }}$ & $q_{\text {Acetate }}$ & $q_{\mathrm{PFL}}$ & $q_{\text {EtOH }}$ & $q_{\mathrm{CO}_{2}}$ & $q_{\mathrm{PDH}}$ & \\
\hline $0 \cdot 10$ & 0.28 & 0.56 & $0 \cdot 31$ & $1 \cdot 15(41 \%)$ & 0.77 & 0.65 & $1.42(51 \%)$ & $0.23(9 \%)$ \\
\hline 0.15 & 0.34 & 0.68 & 0.39 & $1.41(44 \%)$ & 0.77 & 0.64 & $1.41(44 \%)$ & $0 \cdot 35(11 \%)$ \\
\hline $0 \cdot 20$ & 0.38 & 0.79 & 0.42 & $1.59(46 \%)$ & 0.80 & 0.71 & $1.51(44 \%)$ & $0.36(11 \%)$ \\
\hline 0.25 & 0.50 & 1.00 & 0.56 & $2.06(49 \%)$ & 0.98 & 0.81 & $1.79(42 \%)$ & $0.44(10 \%)$ \\
\hline
\end{tabular}

${ }^{*} Y_{\mathrm{x} / \mathrm{s}}, \mathrm{g}$ cells (g sucrose uptake) ${ }^{-1}$.

$\dagger q_{\mathrm{s}}, \mathrm{g}$ sucrose catabolized (g cells) ${ }^{-1} \mathrm{~h}^{-1}$.

$\ddagger q_{\mathrm{EtOH}}$, g aqueous ethanol $(\mathrm{g} \mathrm{cells})^{-1} \mathrm{~h}^{-1}$ (corrected for vapour ethanol losses).

|| Values in parentheses are corrected theoretically for losses as described in the text.

Beusekom et al., 1981). The losses are comparable to the saturation values predicted from the theoretical relations presented by van Beusekom et al. (1981) for the system $\mathrm{CO}_{2}$ /water.

The experimental determination of ethanol and $\mathrm{CO}_{2}$ losses gives an approximate correction, but a better estimate of the true ethanol production can be obtained by calculating theoretical ethanol and $\mathrm{CO}_{2}$ molar yields, as described in Methods. The results summarized in Table 2 show that the experimental ethanol and $\mathrm{CO}_{2}$ measurements were underestimated by approximately $25 \%$ and $40 \%$ respectively.

Table 2 also shows the specific rates of product formation in continuous cultures at four dilution rates, using the theoretical molar yields correction. The specific ethanol productivity $\left(q_{\mathrm{p}}\right)$ for strain LLD-15, corrected for vapour ethanol losses, is $1.5 \mathrm{~g} \mathrm{EtOH}$ (g cells) ${ }^{-1} \mathrm{~h}^{-1}$ at $0 \cdot 25 \mathrm{~h}^{-1}$. This is higher than values reported for other ethanologenic thermophiles (Wiegel et al., 1979; Wiegel \& Ljungdahl, 1981; Kannan \& Mutharasan, 1985) and even mesophilic yeasts $\left(0.87 \mathrm{~g} \mathrm{~g}^{-1} \mathrm{~h}^{-1}\right)$, but lower than the $2.5 \mathrm{~g} \mathrm{~g}^{-1} \mathrm{~h}^{-1}$ reported for the mesophilic Zymomonas mobilis grown on glucose (Rogers et al., 1980).

The volumetric ethanol productivity was within the range $0.55-0.89 \mathrm{~g} \mathrm{l}^{-1} \mathrm{~h}^{-1}$ when corrected for ethanol vapour losses, which is significantly higher than those reported for other thermophiles. This is probably due to the successful establishment of continuous culture; e.g. a volumetric productivity of $0.045 \mathrm{gEtOH} \mathrm{l}^{-1} \mathrm{~h}^{-1}$ can be calculated from the data of Kannan \& Mutharasan 
Table 3. Kinetic data for the continuous culture of B. stearothermophilus $L L D-15$ under anaerobic conditions at $15 \mathrm{~g}$ input sucrose $l^{-1}$ in defined BST-AMM media, pH 7.0, $70^{\circ} \mathrm{C}$

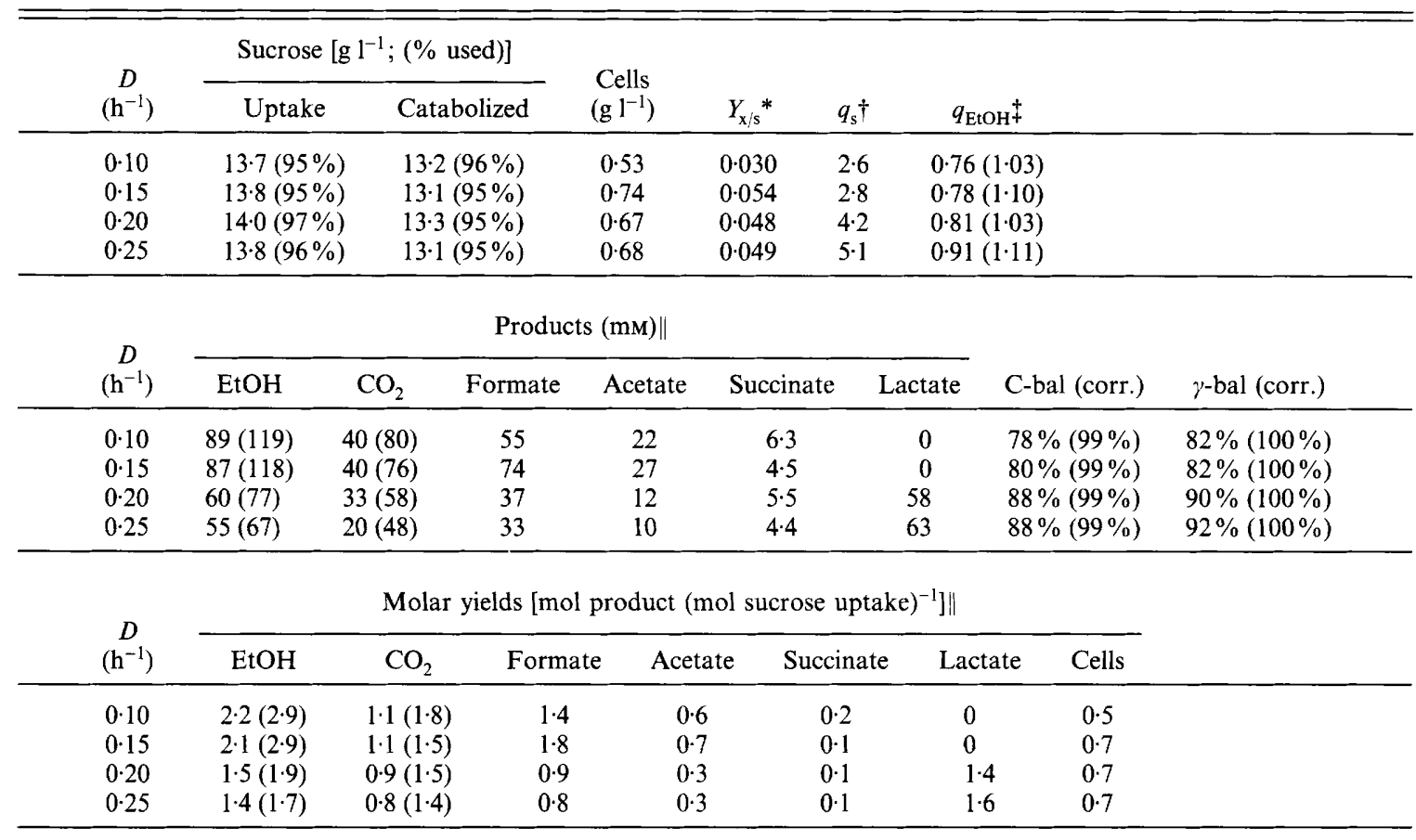

Catabolic pathway fluxes [g product $(\mathrm{g} \text { cells })^{-1} \mathrm{~h}^{-1} ;(\%$ used $\left.)\right] \|$

\begin{tabular}{|c|c|c|c|c|c|c|c|c|}
\hline \multirow{2}{*}{$\begin{array}{c}D \\
\left(\mathrm{~h}^{-1}\right)\end{array}$} & \multicolumn{4}{|c|}{ PFL pathway } & \multicolumn{3}{|c|}{ PDH pathway } & \multirow{2}{*}{$\begin{array}{c}\text { Succinate pathway } \\
q_{\text {Succinate }} \\
\end{array}$} \\
\hline & $q_{\mathrm{EtOH}}$ & $q_{\text {Formate }}$ & $q_{\text {Acetate }}$ & $q_{\mathrm{PFL}}$ & $q_{\mathrm{EtOH}}$ & $q_{\mathrm{CO}_{2}}$ & $q_{\mathrm{PDH}}$ & \\
\hline $0 \cdot 10$ & 0.24 & $0 \cdot 48$ & 0.25 & $0.97(38 \%)$ & 0.79 & 0.66 & $1.47(57 \%)$ & $0 \cdot 14(5 \%)$ \\
\hline $0 \cdot 15$ & $0 \cdot 34$ & 0.69 & 0.33 & $1.36(47 \%)$ & $0 \cdot 76$ & 0.68 & $1.44(49 \%)$ & $0.11(4 \%)$ \\
\hline
\end{tabular}

* $Y_{x / s}, \mathrm{~g}$ cells (g sucrose uptake) ${ }^{-1}$.

$\dagger q_{\mathrm{s}}, \mathrm{g}$ sucrose catabolized (g cells) $)^{-1} \mathrm{~h}^{-1}$.

$\ddagger q_{\mathrm{EtOH}}$, g aqueous ethanol (g cells) ${ }^{-1} \mathrm{~h}^{-1}$ (corrected for vapour ethanol losses).

|| Values in parentheses are corrected theoretically for losses as described in the text.

(1985) for batch cultivation of Thermoanaerobacter ethanolicus on $20 \mathrm{~g}$ glucose $1^{-1}$. Attempts to use continuous culture with other ethanol-producing thermophiles have been less successful. Low ethanol yields were reported for continuous cultures of T. ethanolicus on $60 \mathrm{~g}$ soluble corn starch $\mathrm{l}^{-1}$ (Wiegel et al., 1983) or for Thermoanaerobium brockii (Sonnleitner et al., 1984), even when high amounts of yeast extract were used.

\section{Continuous cultures on 15 and $20 \mathrm{~g}$ sucrose $\mathrm{l}^{-1}$}

Table 3 shows the kinetic parameters and molar yields for strain LLD-15 grown under similar conditions on $15 \mathrm{~g}$ input sucrose $\mathrm{l}^{-1}$. At dilution rates of $0 \cdot 1$ and $0 \cdot 15 \mathrm{~h}^{-1}$, strain LLD-15 was stable and all kinetic parameters and molar yields compared well with those obtained at $10 \mathrm{~g}$ input sucrose $\mathrm{l}^{-1}$. However, above this dilution rate, lactate was detected in the broth indicating take-over by the revertant. Confirmation that this represented reversion rather than the induction of an alternative pathway for lactate synthesis was obtained by (a) demonstrating the presence of $\mathrm{NAD}^{+}$-linked lactate dehydrogenase activity, which was indistinguishable from that present in the wild-type strain in extracts of cells taken from the culture, and $(b)$ demonstrating that the process was irreversible, i.e. high levels of lactate production remained after returning to the lower dilution rates.

Fig. 1 shows $q_{\mathrm{s}}$ as a function of dilution rate for the experiments at 10 and $15 \mathrm{~g}$ input sucrose $\mathrm{l}^{-1}$. It is evident from the change in slope of $q_{\mathrm{s}} / D$ and the appearance of lactate that take-over occurs above a $q_{\mathrm{s}}$ value of $4.2 \mathrm{~g} \mathrm{~g}^{-1} \mathrm{~h}^{-1}$, although the switch point with $15 \mathrm{~g}$ input sucrose $1^{-1}$ appears slightly lower. This could be artifactual, due to a transient increase in $q_{\mathrm{s}}$ above $4.2 \mathrm{~g} \mathrm{~g}^{-1} \mathrm{~h}^{-1}$ when the dilution rate was increased from 


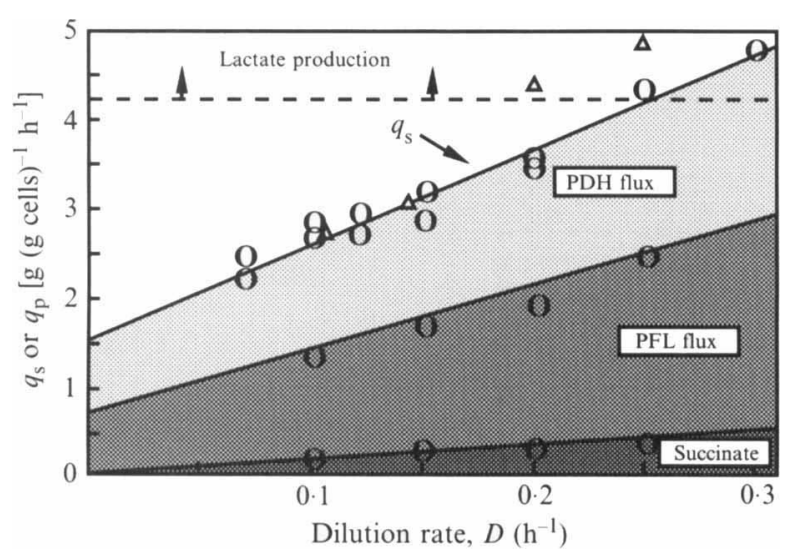

Fig. 1. Specific sucrose consumption rate $\left[q_{\mathrm{s}}, \mathrm{g}\right.$ sucrose $\left.(\mathrm{g} \text { cells })^{-1} \mathrm{~h}^{-1}\right]$ for strain LLD-15 at $10 \mathrm{~g}(O)$ and $15 \mathrm{~g}(\triangle)$ input sucrose $\mathrm{l}^{-1}, 70^{\circ} \mathrm{C}$, $\mathrm{pH} 7.0$. The hatched areas under the $q_{\mathrm{s}}$ line (arrowed) represent the proportion of the total flux from pyruvate which goes via the PDH pathway, PFL pathway and to succinate. When $q_{\mathrm{s}}$ exceeds about $4 \cdot 2 \mathrm{~g}$ sucrose (g cells) $)^{-1} h^{-1}$, LLD-R revertants take over the cultures. The proportion of the pyruvate flux that proceeds through the three catabolic pathways is calculated from the data of Table 2 .

$0 \cdot 15$ to $0 \cdot 2 \mathrm{~h}^{-1}$. Alternatively, it could be due to reduced PFL pathway flux, caused by higher extracellular concentrations of acetate and formate that cause problems with export of these acids (Hartley \& Shama, 1987).

These results support the hypothesis that growth of strain LLD-15 is inhibited at high $q_{\mathrm{s}}$ because flux through both the PFL and PDH pathways becomes saturated. At $\mathrm{pH} \mathrm{8.5,} \mathrm{the} \mathrm{carbon} \mathrm{metabolic} \mathrm{flux} \mathrm{in} \mathrm{LLD-15} \mathrm{at} \mathrm{moderate}$ growth rates is almost entirely through the PFL pathway (Hartley \& Shama, 1987). However, flux through PDH increases at more acid $\mathrm{pH}$. Therefore it has been proposed that the PDH pathway is induced because flux through PFL becomes limiting as a result of end-product inhibition, which would be exacerbated at lower $\mathrm{pH}$ because of diffusion of acetic and formic acids (protonated) back into the cells (Hartley \& Shama, 1987). Evidence in Tables 2 and 3 that the relative flux shifts from PDH to the (already restricted) PFL pathway with increasing growth rate indicates that flux through both pathways is becoming increasingly restricted. It is also significant that pyruvate excretion is seen just before production of lactate is observed. Under these conditions, strain LLD-15 approaches its $\mu_{\max }$, but the revertant strain LLD-R has a higher $\mu_{\max }$ because it can divert the excess pyruvate to L-lactate.

The molar yields obtained in batch experiments using $20 \mathrm{~g}$ input sucrose $1^{-1}$ were comparable to the experiments with 10 and $15 \mathrm{~g}$ input sucrose $1^{-1}$. However, shortly after continuous operation was started $(D=$ $\left.0 \cdot 1-0 \cdot 15 \mathrm{~h}^{-1}\right)$, cell density dropped and cell lysis was detected in the broth. This was followed by take-over by a lactate-producing revertant.
Several experiments were performed to determine the cause of growth inhibition at $20 \mathrm{~g}_{\text {sucrose }} \mathrm{l}^{-1}$. These included: increase and decrease of medium components, change of base to $\mathrm{NH}_{4} \mathrm{OH}$ to check possible inhibition by $\mathrm{K}^{+}$as reported by Atkinson et al. (1975), and different protocols for initiating continuous culture (e.g. exponential growth vs stationary phase). However, all these experiments gave similar results, and it was therefore considered that accumulated ethanol or acids were the cause, as observed in batch cultures by Shama \& Hartley (1987).

To test this hypothesis, continuous culture was performed with $20 \mathrm{~g}$ input sucrose $\mathrm{l}^{-1}$ at a high nitrogen sparging rate to aid removal of ethanol from the broth. This allowed establishment of a steady state at $0 \cdot 1 \mathrm{~h}^{-1}$, in which the residual sucrose, $\mathrm{CO}_{2}$ levels and acid concentrations were comparable to those obtained at $10 \mathrm{~g}$ input sucrose $1^{-1}$, indicating similar theoretical ethanol yields though vapour ethanol losses were now severe.

\section{Effect of $p H$}

Although ethanol removal allowed for operation at higher substrate input concentrations, ethanol yields remained low, at approximately $70 \%$ of the maximum theoretical (i.e. 4 mols EtOH per mol of sucrose). Hartley \& Shama (1987), working with batch cultures, found that the production of ethanol by strain LLD-15 was improved at acid $\mathrm{pH}(\mathrm{pH}$ 6.2). A plausible explanation is that excretion of acetic and formic acid becomes increasingly difficult with reduction in $\mathrm{pH}$, inducing a relatively higher flux through the $\mathrm{PDH}$ pathway to metabolize the resulting excess pyruvate.

To achieve further process improvement, a series of experiments were performed at $\mathrm{pH} 6 \cdot 5$, both at 10 and $15 \mathrm{~g}$ input sucrose $1^{-1}$. Unfortunately, the system was highly unstable, and both cell density and sucrose consumption were significantly lower than at $\mathrm{pH} 7 \cdot 0$. After $10-15 \mathrm{~h}$, lactate was detected in the broth, indicating take-over by LLD-R.

\section{Estimation of maintenance energy at $1 \%(w / v)$ input sucrose}

Maintenance energy is defined as the energy consumed for purposes other than the production of new cell biomass, e.g. to balance decay in intracellular proteins and metabolites, osmotic regulation, maintenance of intracellular $\mathrm{pH}$ and motility (Dawes, 1986). Generally, the maintenance energy coefficient, $m_{\mathrm{s}}$, is estimated from continuous culture experiments, using the relation between growth yield, $Y_{\mathrm{x} / \mathrm{s}}$, and specific growth rate, $\mu$, introduced by Pirt (1965).

$$
1 / Y_{\mathrm{x} / \mathrm{s}}=m_{\mathrm{s}} / \mu+1 / Y_{\mathrm{x} / \mathrm{smax}}
$$


However, this expression is only valid when the amount of energy derived from the growth substrate is constant at all dilution rates (De Vries et al., 1970). In the case of strain LLD-15, the flux through acetate kinase, which generates one ATP more than the PDH flux, depends on the dilution rate (see Table 2). However, the following relation still holds.

$$
1 / Y_{\mathrm{ATP}}=m_{\mathrm{s}} / \mu+1 / Y_{\mathrm{ATP}(\max )}
$$

where $Y_{\mathrm{ATP}(\max )}$ is the growth yield per mol of ATP, corrected for maintenance energy, $m_{\mathrm{s}}$ is the amount of ATP required for maintenance $\left[\mathrm{mmol} \operatorname{ATP}(\mathrm{g} \text { cells })^{-1} \mathrm{~h}^{-1}\right]$ and $Y_{\text {ATP }}$ is the apparent growth yield per mol of ATP (De Vries et al., 1970).

A plot of $1 / Y_{\mathrm{ATP}}$ vs $1 / D$ was made for strain LLD-15 at $10 \mathrm{~g}$ input sucrose $\mathrm{I}^{-1}$, within the stable range (i.e. $\left.0 \cdot 1-0 \cdot 25 \mathrm{~h}^{-1}\right)$. The calculation of $Y_{\mathrm{ATP}}$ assumed that sucrose is converted to two hexose phosphates via a sucrose phosphorylase (Gottschalk, 1979), although this remains to be established. Hence 5 ATPs would be generated in converting sucrose to pyruvate and 1 ATP would be produced in the acetate kinase step of the PFL pathway. Using linear regression analysis, and considering that in continuous culture $\mu=D$, the following relation was obtained.

$$
1 / Y_{\text {ATP }}=29 \cdot 6 / \mu+152 \cdot 1 \quad R=0.99
$$

This gives $m_{\mathrm{s}}=29.6 \mathrm{mmol} \mathrm{ATP}(\mathrm{g} \text { cells })^{-1} \mathrm{~h}^{-1}$ and $Y_{\mathrm{ATP}(\max )}=6.6 \mathrm{~g}$ cells $(\mathrm{mol} \mathrm{ATP})^{-1}$. A similar analysis, assuming that only 4 mols of ATP are generated per mol of sucrose, yields $m_{\mathrm{s}}=23.0 \mathrm{mmol}$ ATP $(\mathrm{g} \text { cells })^{-1} \mathrm{~h}^{-1}$ and $Y_{\mathrm{ATP}(\max )}=7.4 \mathrm{~g}$ cells $(\mathrm{mol} \mathrm{ATP})^{-1}$. Compared to anaerobic mesophilic micro-organisms, this value of $Y_{\mathrm{ATP}(\max )}$ is low while $m_{\mathrm{s}}$ is relatively high (Esenert et al., 1981), supporting the argument of Zeikus (1979) that high maintenance energy is an inherent characteristic of extreme thermophiles. High maintenance requirements have also been reported for aerobic non-ethanologenic thermophilic bacteria such as Thermus thermophilus (Sonnleitner et al., 1982). The maintenance energy for Thermoanaerobium brockii in continuous culture at $70^{\circ} \mathrm{C}$ was recently estimated as $0.5 \mathrm{~g}$ glucose $(\mathrm{g} \text { cells })^{-1} \mathrm{~h}^{-1}$ (Sonnleitner et al., 1984), compared with the $1.5 \mathrm{~g}$ sucrose ( $\mathrm{g}$ cells $)^{-1} \mathrm{~h}^{-1}$ derived from Fig. 1. However more detailed comparison with this work is not possible, since the end-product compositions for T. brockii were not reported.

\section{Relative flux through the PFL, PDH and succinate pathways}

The above data make it possible to estimate the relative flux through the PDH, PFL and succinate pathways at different growth rates, as shown in Tables 2 and 3, and the fluxes at $10 \mathrm{~g}$ input sucrose $\mathrm{l}^{-1}$ at $\mathrm{pH} 7$ are illustrated in Fig. 1. At low dilution rates, the PDH pathway predominates, but at higher growth rates the PDH flux declines and the relative amount of flux through the PFL and succinate pathways increases. For example, of the total increase in pyruvate flux to products between $D=$ $0.1 \mathrm{~h}^{-1}$ and $D=0.25 \mathrm{~h}^{-1}, 60 \%$ was diverted through the PFL pathway, $27 \%$ through the PDH pathway and $13 \%$ through the succinate pathway. As discussed, this suggests that the PDH pathway was becoming saturated under the conditions studied, and that increased carbon flow was diverted preferentially through the PFL pathway at a higher $q_{\mathrm{s}}$.

Previous results in batch cultures have shown that both growth and PFL flux decline at acid $\mathrm{pH}$ and/or when acetate and formate accumulate in the medium (Hartley \& Shama, 1987), which has been ascribed to difficulty in excreting acetic and formic acids against a concentration and $\mathrm{pH}$ gradient. The consequent decline in flux through the acetate pathway would slow up the regeneration of free $\mathrm{CoA}$, which is a co-substrate for PDH. Hence flux through that pathway may also decline through shortage of free CoA, so growth inhibition and pyruvate accumulation would be enhanced.

These considerations make it clear that single-stage continuous culture is not a suitable mode for commercial production of ethanol by this mutant thermophile, even if non-reverting strains were selected, since maximum ethanol yields via the PDH pathway are shown by nongrowing cells operating under conditions of high maintenance metabolism. Hence dilution rates should be very low to avoid wash-out.

\section{Appendix: Nomenclature}

The following abbreviations are used throughout the paper.

$C_{\mathrm{s}} \quad$ Concentration of limiting carbon source $\left(\mathrm{g}^{-1}\right)$

$C_{\text {So }}$ Incoming concentration of limiting carbon source $\left(\mathrm{g}^{-1}\right)$

$C_{\mathrm{x}} \quad$ Concentration of cells $\left(\mathrm{g}^{-1}\right)$

$C_{\mathrm{p}} \quad$ Concentration of product $\left(\mathrm{g} \mathrm{l}^{-1}\right)$

$D \quad$ Dilution rate $\left(\mathrm{h}^{-1}\right)$

$\mu \quad$ Specific growth rate $\left(\mathrm{h}^{-1}\right)$

$m_{\mathrm{s}} \quad$ Maintenance factor based on substrate requirements [g substrate consumed ( $\mathrm{g}$ cells $)^{-1} \mathrm{~h}^{-1}$ ]

$n_{\mathrm{C} / \mathrm{S}} \quad$ C-mols per mol of sugar

$n_{\mathrm{C} / \mathrm{pi}} \quad \mathrm{C}$-mol per mol of product $\mathrm{i}$

$n_{\mathrm{C} / \mathrm{x}} \quad$ C-mols per mol of cells

$Y_{\mathrm{pis}} \quad$ Mols of product i per mol of sugar fermented

$Y_{\mathrm{x} / \mathrm{S}} \quad$ Mols of cells per mol of sugar fermented 
$Y_{\mathrm{x} / \mathrm{s}} \quad$ Yield factor of biomass on substrate [ $\mathrm{g}$ cells ( $\mathrm{g}$ substrate consumed) ${ }^{-1}$ ]

$Y_{\mathrm{x} / \mathrm{p}} \quad$ Yield factor of biomass on product $[\mathrm{g}$ cells ( $\mathrm{g}$ product produced $\left.)^{-1}\right]$

\section{References}

Amartey, S., Leak, D. J. \& Hartley, B. S. (1991). Development and optimization of a defined medium for aerobic growth of Bacillus stearothermophilus LLD-15. Biotechnology Letters 13, 621-626.

Atkinson, A., Evans, C. G. T. \& Yeo, R. G. (1975). Behaviour of Bacillus stearothermophilus grown in different media. Journal of Applied Bacteriology 38, 301-304.

DAWES, E. A. (1986). Microbial Energetics. Glasgow: Blackie and Son.

De Vries, W., Kapteyn, W. M. C., van Der Beek, E. G. \& Stouthamer, A. H. (1970). Molar growth yields and fermentation balances of Lactobacillus case $\mathrm{L} 3$ in batch cultures and in continuous cultures. Journal of General Microbiology 63, 333-345.

Esenert, A. A., Roels, J. A. \& Kossen, N. W. F. (1981). Comments on the description of maintenance metabolism during anaerobic growth with product formation. Biotechnology Letters 3, 15-20.

GotTschalk, G. (1979). Bacterial Metabolism, p. 114. New York: Springer-Verlag.

HARTLEY, B. S. (1988). Thermophilic ethanol production. International Patent Application UK 8712410.

HaRTLEY, B. S. \& Shama, G. (1987). Novel ethanol fermentations from sugar cane and straw. Philosophical Transactions of the Royal Society A321, 555-568.

Kannan, V. \& Mutharasan, R. (1985). Ethanol fermentation characteristics of Thermoanaerobacter ethanolicus. Enzyme and Microbial Technology 7, 87-89.

Maiorella, B., BlanCH, H. \& Wilke, C. (1984). Economic evaluation of alternative ethanol fermentation processes. Biotechnology and Bioengineering 26, 1003-1025.
Payton, M. A. \& Hartley, B. S. (1985). Mutants of Bacillus stearothermophilus lacking NAD-linked L-lactate dehydrogenase. FEMS Microbiology Letters 26, 333-336.

PirT, S. J. (1965). Principles of Microbe and Cell Cultivation. Oxford: Blackwell Scientific.

RoEls, J. A. (1980). Application of macroscopic principles to microbial metabolism. Biotechnology and Bioengineering 22, 2457-2514.

Rogers, P. L., Lee, K. J. \& Tribe, D. E. (1980). High productivity ethanol fermentations with Zymomonas mobilis. Process Biochemistry (August/September), 7-11.

San Martin, R., Bushell, D., Leak, D. J. \& Hartley, B. S. (1992). Development of a synthetic medium for the continuous cultivation of a mutant of Bacillus stearothermophilus lacking L-lactate dehydrogenase. Journal of General Microbiology 138, 987-996.

SONNLeITNER, B., CometTA, S. \& FieChTER, A. (1982). Growth kinetics of Thermus thermophilus. European Journal of Applied Microbiology and Biotechnology 15, 75-82.

SONNLEITNER, B., FieCHTER, A. \& Grovannini, F. (1984). Growth of Thermoanaerobium brockii in batch and continuous cultures at supraoptimal temperatures. Applied Microbiology and Biotechnology 19, 326-332.

Van Beusekom, C. N., De Rok, H. E. \& Roels, J. A. (1981). A method for the determination of dissolved carbon dioxide. Biotechnology and Bioengineering 23, 2397-2401.

WIEGEL, J. \& LJUNDAHL, L. G. (1981). Thermoanaerobacter ethanolicus gen. nov. spec. nov., a new extreme thermophilic, anaerobic bacterium. Archives of Microbiology 128, 343-348.

WiEgel, J., LJUNGDAHL, L. G. \& Rawson, J. R. (1979). Isolation from soil and properties of extreme thermophile Clostridium thermohydrosulfuricum. Journal of Bacteriology 139, 800-810.

Wiegel, J., Carreira, L. H., Mothershed, Ch. P \& Puls, J. (1983). Production of ethanol from biopolymers by anaerobic, thermophilic and extreme thermophilic bacteria. II. Thermoanaerobacter ethanolicus JW 200 and its mutants in batch cultures and resting cell experiments. Biotechnology and Bioengineering Symposium no. 13, 193-205.

ZEIKUS, J. G. (1979). Thermophilic bacteria: ecology, physiology and technology. Enzyme and Microbial Technology 1, 243-252. 